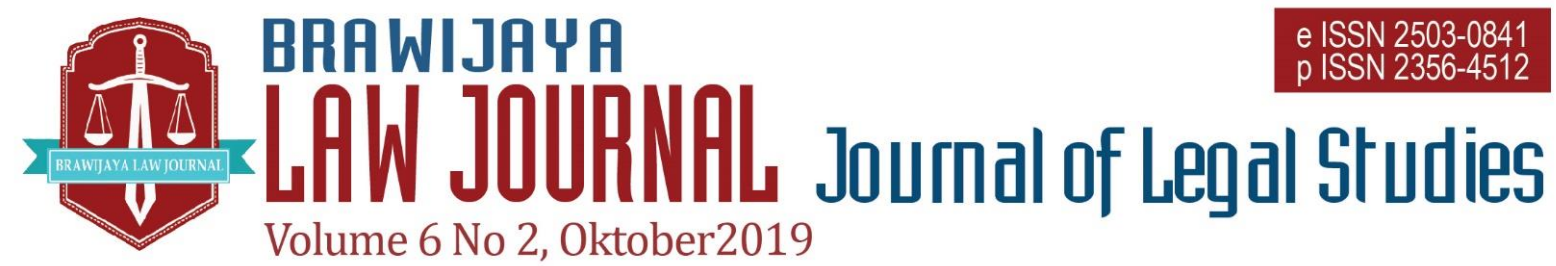

Nationally Accredited No. 30/E/KPT/2018 Dated 24th October 2018

This work is licensed under a Creative Commons Attribution-NonCommercial 4.0 International License

\title{
Compensation as Sanctions for the Perpetrators of Corruption in the Dimensions of Indonesian Criminal Law Renewal
}

\author{
Kukuh Dwi Kurniawana, Dwi Ratna Indri Hapsari ${ }^{\text {b }}$ \\ Yaris Adhial Fajrinc, Ach. Faisol Triwijaya ${ }^{d}$ \\ ${ }^{a}$ Law Faculty of University of the Muhammadiyah Malang, \\ Email: kukuhdwik@gmail.com \\ ${ }^{b}$ Law Faculty of University of the Muhammadiyah Malang, \\ Email: indri3009@gmail.com \\ ${ }^{c}$ Law Faculty of University of the Muhammadiyah Malang, \\ Email: yarisroyaadhifa@gmail.com \\ ${ }^{\mathrm{d} S t u d e n t}$ of Law Master in the Faculty of Law, Universitas Brawijaya, \\ Email: achfaisolt@yahoo.com.
}

Submitted : 2019-08-02 | Accepted : 2019-10-14

\begin{abstract}
Corruption is one of the negative consequence of corporate crime. Corruption perpetrators from corporations are still relatively new in Indonesia, so legal reform is still needed, which is close to the purpose of criminal law. The existence of legal sanction in the form of compensation becomes a breakthrough for one type of sanction and can impose the perpetrator of corruption. Thus, in this study, we want to find a theoretical basis for corporate punishment that commits corruption and the existence of criminal sanctions for corporate compensation as perpetrators of corruption in efforts to renew criminal law. This study uses normative research by approaching the conceptual approach. From this research, finding a corporate foundation that commits corruption can be imposed by a criminal is in line with the purpose of punishment as well as by ius constituendum. For compensation that is an alternative to corporate punishment as a perpetrator of corruption, it can be brought down along with the principal penalty which has the purpose of accountability and reconciliation, guidance, reintegration, socialization or means of resolving conflicts to the community.
\end{abstract}

Keywords: compensation sanction; corporation; corruption.

\section{INTRODUCTION}

Changes in society that occur are caused by systems that are integrated into the lives of the people that are related to each other. According to Talcot Parsons, the system consists of four sub-systems that influence each other, which include economics, politics, law and culture, of which the four economic sub-systems have the strongest influence that can change the 
three sub-systems. ${ }^{1}$ Economic changes that are in line with the flow of globalization, also have an effect on changes in people's behaviour which shows the existence of a corporate dimension in people's living systems, so that corporate growth continues to increase rapidly from the number and size. This illustrates that community activities in the economic, social, and political fields are largely influenced by corporate behaviour so that corporations have an important role in the development process in the economic and other living systems.

The role of corporations in the development of their activities can increase economic growth through the inclusion of the state in the form of taxes and even foreign exchange, as well as the provision of extensive employment for the community. ${ }^{2}$ In 2019 the corporate role of the tax sector showed an increase of $0.94 \%$ from the previous year. ${ }^{3}$ With this, the existence of corporations has an influential impact on the country's economy. The power of economic development forces the law to adapt and follow the changes that occur as a means of disciplining the community, because these developments can have a negative effect in the form of the birth of new crimes using corporate means ${ }^{4}$, because the corporation is used as a means to get the maximum profit often causes lawlessness ${ }^{5}$ and bring negative

1 Raf Vanderstraeten, 'Systems Everywhere?' (2019), 36.3 (April) Systems Research and Behavioral Science 1-8, p. 3-4.

2 Lilik Shanty, 'Aspek Teori Hukum Dalam Kejahatan Korporasi' (2017), 3.1 (January-June) Pakuan Law Review 56, 60.

3 Agatha Olivia Victoria, 'Penerimaan Pajak Hingga Juli 2019 Hanya Tumbuh 2,68\%',

Katadata.Co.Id, 2019, <https://katadata.co.id/berita/2019/08/26/penerim aan-pajak-hingga-juli-2019-hanya-tumbuh-268>, date accesed: 9 October 2019.

4 Muladi and Dwiwidja Priyatno, Pertanggungjawaban Pidana Korporasi (Jakarta: Kencana, 2015), p.3. consequences to others even to the wider community. ${ }^{6}$

One of the characteristics of industrial society is the widespread and powerful corporation, both as economic actors and in social life in general. ${ }^{7}$ Government policies that are oriented towards economic development, one of which is through the establishment of various industries whose operations are largely played by corporations, often leading to deviant behaviour. This corporate behaviour deviation in its activities was later known as corporate crime. ${ }^{8}$

Corporate crimes can be interpreted as an organizational crime who committed crimes in the sector financial manipulation, accounting fraud, food fraud, cartels, bribery, toxic spills and environmental harms. ${ }^{9}$ The emergence of the term corporate crime led to several forms of criminal acts entering into a part of the corporate crime, one of which was corruption. This can be seen in the regulation of the subject of corporate law in Law Number 31 Year 1999 concerning the Eradication of Corruption Crimes juncto Law Number 20 Year 2001 concerning Amendment to Law 31 of 1999 concerning the Eradication of Corruption Crimes (hereinafter referred to as the Corruption Law), namely in article 1 paragraph (1), which reads Corporations are groups of

5 Puteri Hikmawati, 'Kendala Penerapan Pertanggungjawaban Pidana Korporasi Sebagai Pelaku Tindak Pidana Korupsi' (2017), 8.1 (June) Jurnal Negara Hukum 131, 132 .

6 Munir Fuady, Teori-Teori Besar (Grand Theory) Dalam Hukum, (Jakarta: Kencana, 2013), p. 196.

7 I.S. Susanto, Kejahatan Korporasi (Semarang: Badan Penerbit Universitas Diponegoro, 1995), p.19.

8 Lilik Shanty, above n 2, 60.

9 Judith van Erp, 'The Organization of Corporate Crime: Introduction to Special Issue of Administrative Sciences' (2018), 8.3 (July) Administrative Sciences 36, 1. 
people and/or assets that are organized either as legal entities or not legal entities.

Law enforcement efforts against corporations that make corruption were carried out by law enforcement in this country. Beginning in the case of PT. Giri Jaladhi Wana was submitted as a defendant by the Prosecutor's Office and was prosecuted to court corruption in 2010, where it was the first corporation to be made a defendant and convicted. ${ }^{10}$ Then there is also PT. Duta Graha Indah, who is now PT. Nusa Konstruksi Enjiniring (PT NKE) in 2017, was investigated by the Corruption Eradication Commission (KPK) and was named a suspect in a corruption case at the hospital building project at Udayana University. ${ }^{11}$ PT NKE was convicted of a criminal act of corruption and was sentenced in the form of a fine of 700 million rupiahs and an additional penalty in the form of payment of replacement money of $85,490,234,737$, as well as revocation of the right to participate in the auction of goods/services to government agencies. ${ }^{12}$ If interpreting the law as an effort to countermeasure crime, repressive law enforcement, Hoefnagels refer to it as part of criminal policy. The verdict on PT. NJE above is a depiction of criminal law enforcement efforts in Indonesia leading to the company as a criminal corruption perpetrator.

The spirit of law enforcement on the

10 Budi Suhariyanto, 'Progresivitas Putusan Pemidanaan Terhadap Korporasi Pelaku Tindak Pidana Korupsi' (2016), 16.2 (June) De Jure 201, 207. Through Decision Number 812 / Pid.Sus / 2010 / PN.Bjm, it was decided that PT GJW had been legally and convincingly proven guilty of committing criminal acts of corruption continuously and was convicted of a fine of Rp1,300,000,000, and additional criminal sanctions in the form of temporary closure six months. On appeal, the Banjarmasin High Court upheld the previous Decision. corporate law subject is currently experiencing obstacles, one of which is caused by the lack of regulation of the legal subject in the current Indonesian Criminal Code (KUHP). The subject of corporate law is still partially regulated and spread in various laws outside the Criminal Code. Taking into account these obstacles, the Mahkamah Agung ${ }^{13}$ (MA) issued a Peraturan Mahkamah Agung (PERMA) Number 13 Year 2016 concerning Procedures for Handling Criminal Cases by Corporations, to overcome the insecurity of law enforcers in prosecuting corporations as perpetrators of crimes. Law enforcement for corporations as perpetrators of the crime as well as subjects of criminal law will have implications for the form and type of criminal sanctions and their punishment. Throughout the author's coronation and by looking at Munir Fuady's ${ }^{14}$ opinion, until the year 2019 in Indonesia there are various types and forms of criminal sanctions that can be imposed on corporations, such as: fines, revocation of licenses, dissolution of corporations, compensation, obligation to do something, statements of apology to the people or to other parties who have been harmed, or revocation of rights certain other.

Especially for sanctions damages, has not been known in the Corruption Law because the law only recognizes some types of sanctions that can be imposed on a corporation, namely: first, Confiscation of

11 Budi Suhariyanto, 'Pertanggungjawaban Pidana Korporasi Berdasarkan Corporate Culture Model Dan Implikasinya Bagi Kesejahteraan' (2017), 6.3 (December) Rechsvinding 441, 444.

12 Dylan Aprialdo Rachman, 'Perjalanan Kasus PT NKE, Korporasi Pertama Yang Divonis Korupsi', Kompas.Com, 2019 , <https://kilaskementerian.kompas.com/kemenpar/ $\mathrm{read} / 2019 / 01 / 04 / 06115311 /$ perjalanan-kasus-ptnke-korporasi-pertama-yang-divonis-korupsi>, date accesed: 1 July 2019.

13 Indonesia Supreme Court

14 Munir Fuady, above n 6, p.196. 
movable or immovable goods used or gained from corruption ; second, the payment of as much substitute money as possible with the property obtained from criminal acts of corruption; third, closure of all or part of the company for a maximum of 1 (one) year; and fourth, revocation of all or part of certain rights or the elimination of all or part of certain benefits. There has been the threat of additional criminal sanctions in the form of payment of substitute money, but this is only intended as a means of returning state losses ${ }^{15}$ due to the corruption committed by the perpetrators. Corruption crimes committed by corporations have extensive consequences and victims, not only the state but the people will likely become victims.

Compensation for corporations committing crimes is known in positive criminal law in Indonesia, which is contained in Law Number 8 Year 1999 concerning Consumer Protection, namely Article 63. Seeing the existence of rules regarding compensation sanctions by the corporation, then there is no harm if the sanctions are considered as an alternative sanction for corporations in criminal acts of corruption. So through this paper, the author will explain how the idea of criminal sanctions in the form of compensation is applied to corporations that are perpetrators of criminal acts of corruption, as a discourse on criminal law reform, especially regarding the types and forms of sanctions against corporations. In connection with the description of the background above, the author raised two formulations of the problem as the subject of the study in this article, what is the theoretical foundation for criminal prosecution of

15 Nur Syarifah, 'Mengupas Permasalahan Pidana Tambahan Pembayaran Uang Pengganti Dalam Perkara Korupsi', Lembaga Kajian \& Advokasi Independensi Peradilan, 2015, $<$ http://leip.or.id/mengupas-permasalahan-pidana- corporations committing corruption? And what are the ideas of compensation sanctions for corporate actors in criminal acts of corruption in the dimension of criminal law reform?

\section{LEGAL MATERIALS AND METHODS}

This research uses a normative research method, which is to examine the law at the norm level with the point of pressing the Corruption Crime law, especially the articles relating to the corporation as the subject of criminal law and the system of giving sanctions. The approach used is the conceptual approach as part of the solution to the problem. The author uses the concept of compensation sanctions as a solution to address the issue of corruption crimes committed by corporations, moreover, the type of sanctions are not known in the positive criminal law in Indonesia. Then the primary data source comes from book, journals and data from online media as secondary data sources which are then processed descriptively.

\section{RESULT AND DISCUSSION}

\section{a. Foundations and Purpose Corporations Doing Punishment against Crime}

The influence of economic development in criminality is a significant factor, thus encouraging the involvement of corporations in a criminal act, such as tax fraud, environmental damage, and in the sector of misuse of state finance that has an impact on the destruction of the lives of the wider community. ${ }^{16}$ Corporate growth along

tambahan-pembayaran-uang-pengganti-dalamperkara-korupsi/>, date accesed: 21 July 2019.

16 Muladi and Dwiwidja Priyatno, above n 4, p. 4243. 
with the negative effects it brings, such as environmental pollution, tax manipulation, labour exploitation which will cause business failure. ${ }^{17}$ This led to developments in the existence of corporations as legal subjects, who initially as subjects of ordinary law became the subject of criminal law.

The development of the corporation as a subject of law cannot be separated from social modernization which can have an impact on the economy, social, politics, thus according to Satjipto Rahardjo, the development of social modernization requires a control system that can balance so that the orderly society is maintained. ${ }^{18}$ The lawmakers initially held that only humans (individuals or individuals) could be the legal subject of a crime, which can be seen from the history of Article 59 of the Criminal Code, especially how the offence was formulated with the phrase "hij die" which means "whoever". 19

The function of criminal law protects the community when it only emphasizes the imposition of criminal acts on individuals or individuals as legal subjects, the function cannot work. The function of criminal law cannot be carried out when it is only focused on individuals as legal subjects because at this time the corporation can also commit criminal acts.

Corporations that commit criminal acts can be referred to as corporate crime, which is classified as the White Collar Crime (WCC). Corporate crime as a WCC uses a sophisticated modus operandi that can be transnational in nature because it is carried

17 Martin S Bressler, 'The Impact of Crime on Business : A Model for Prevention, Detection \& Remedy' (2009), 7.5 (May) Journal of Management and Marketing Research 1, 10.

18 Social modernization is a community change in life patterns because of the influence of outside culture and globalization. See: Muladi and Dwiwidja Priyatno, above n 4, p. 44. out across countries and territories, resulting in a wide scope of crimes and the impact of very large losses. The extent of the dimension of crime has implications for the expansion of the dimensions of victims of corporate crime that encompass society in general. ${ }^{20}$ Even according to Kristian, the state can also be a victim of corporate crime in the form of state financial losses or the country's economy. ${ }^{21}$

Seeing the qualifications of transnational crime, corruption can also be classified as a transnational crime, so it does not rule out the possibility of criminal acts of corruption carried out by legal subjects in the form of corporations. Law enforcement for corporations that commit corruption by making it the subject of criminal law will result in the functioning of criminal law in protecting the wider community, as well as the interests of the state in general. Besides, in the development of crime and criminal law, it began to take into account the fact that humans also sometimes carry out actions within or through organizations in civil law, so that arrangements exist for legal entities or corporations as subjects of law in criminal law. ${ }^{22}$

Addressing corporations as a legal subject cannot be released from the viewpoint of civil law, because it is civil law that has a lot to do with corporate issues and at the same time initiates discussions about corporations as legal subjects. "Person" in the view of civil law means the bearer of rights or legal subject (subjectum juris), but that is not the only legal subject (natuurlijke

19 Budi Suhariyanto, above n 11, 442.

20 Budi Suhariyanto, ibid.

21 Kristian, Hukum Pidana Korporasi: Kebijakan Integral (Integral Policy) Formulasi Pertanggungjawaban Pidana Korporasi Di Indonesia, (Bandung: Nuansa Aulia, 2014), p. 33.

22 Eddy O.S. Hiariej, Prinsip-Prinsip Hukum Pidana, (Yogyakarta: Cahaya Atma Pustaka, 2014), p. 155. 
persoon) because there are still other legal subjects who according to the law can have rights and do legal acts like a human being, so that he has his wealth and by means of his management can be sued and sued before the court. ${ }^{23}$ The legal subject in question is a legal entity (rechtspersoon) which means a person created by law. ${ }^{24}$ It's just that corporations according to civil law have a narrower understanding than in criminal law. According to criminal law, the corporation can be a legal entity or non-legal entity, whereas according to civil law the corporation has a legal entity. ${ }^{25}$

The emergence of the corporate crime concept in the theory of criminal law according to Munir Fuady, is interpreted as an act of doing or not acting by a legal entity or body that carries or is expected to bring benefits to a legal entity or association by breaking the law, which resulting in losses to other people or to society at large. ${ }^{26}$ The corporation was known as the subject of criminal law since the Emergency Law Number 7 Year 1955 concerning Investigation, Prosecution and Economic Criminal Justice, which is mentioned by the name of the legal entity, company, association or foundation. ${ }^{27}$ The Indonesian Criminal Code currently does not place corporations as the subject of criminal law, but various laws and regulations that exist outside the Criminal Code have recognized and placed corporations as subjects of criminal law other than humans. Muladi and Diah Sulistyani said there was about 62 legislation in Indonesia that regulated criminal liability by corporations ${ }^{28}$, such as detailed in the following table:

\section{REGULATION}

Emergency Law Number 7 Year 1955 concerning Investigation, Prosecution and Economic Criminal Justice

Law Number 31 Year 1999 in conjunction with law number 20 Year 2001 concerning the Eradication of Corruption Crimes

Law number 8 Year 2010 concerning Prevention and Limitation of Money Laundering Crimes

Law number 35 Year 2009 concerning Narcotics

Law number 8 Year 1999 concerning Consumer

Protection

Law number 22 Year 2001 concerning Oil and Gas Law number 32 Year 2009 concerning Environmental Protection and Management

The table illustrates that corporations as the subject of criminal law have been known and spread in various rules in Indonesia, including the Corruption Law. It

23 Lilik Shanty, above n 2, 57.

24 Subekti, Pokok-Pokok Hukum Perdata, (Jakarta: Intermasa, 1984), p. 21.

25 Muladi and Dwiwidja Priyatno, above n 4, p. 33.

26 Munir Fuady, above n 6, p. 195.

27 Putri Hikmawati, 'Kendala Penerapan Pertanggungjawaban Pidana Korporasi Sebagai provides consequences Corporate need to be constructed as the subject of criminal law. The author also cites the opinion of Steven Box, where corporations are used as the

Pelaku Tindak Pidana Korupsi' (2017) 8(1) Negara Hukum, p 133.

28 Muladi and Diah Sulistyani, Pertanggungjawaban Pidana Korporasi (Bandung: Alumni, 2013), p. 50-53. 
subject of criminal law when crimes for corporations occur, namely crimes committed by corporations in achieving certain businesses and objectives to gain profits. ${ }^{29}$

Furthermore, the reasons for corporations can be used as subjects of criminal law are based on a study conducted by the Criminal Law Team, the Badan Pembangunan Hukum Nasional (BPHN), which concludes that only the corporation management does not guarantee that the corporation will not do any prohibited laws. ${ }^{30}$ The draft National Criminal Code began to include corporations as subjects of criminal law, as stated in the following formulation of Article 46:

1) The Corporation is the subject of Criminal Actions;

2) Corporations as referred to in paragraph (1) include legal entities in the form of limited liability companies, foundations, cooperatives, state-owned enterprises, regionally owned enterprises, or those that are equated with them, as well as legal entities or non-legal entities or business entity in the form of a firm, partnership, or equivalent to it by the provisions of the legislation.

This illustrates that the Indonesian

29 Kristian, 'Urgensi Pertanggungjawaban Pidana Korporasi' (2014), 44.4 (October-December) Jurnal Hukum dan Pembangunan 575, 587.

30 Muladi and Dwiwidja Priyatno, above n 4, p. 151.

31 Bilal Ramadhan, 'Ini Kronologis Kasus Bank Century', Republika.Co.Id, 2014, <https://www.republika.co.id/berita/nasional/huk um/14/03/06/n20q0m-ini-kronologis-kasus-bankcentury>, date accesed: 21 July 2019.

32 The purpose of absolute punishment is trapping through criminal imposition in accordance with the actions committed, retaliation is the legitimacy of punishment. Vos believes that crime is seen as the basis of the involvement of the perpetrators. The answer to absolute theory is a relative theory called criminal law in the future will include corporations as subjects of criminal law in addition to the legal subjects of people, so that in terms of criminal matters and punishment they must have aspired in line with the renewal of Indonesian criminal law.

Especially for corporate subjects in criminal acts of corruption, the definition of "person" is not merely interpreted as a human being but also includes a corporation, as stated in Article 1 point 3 of the Corruption Law. The aim is to punish corporations as perpetrators of corruption based on negative impacts in the form of profits that are obtained by corporations against the law (contrary to law) and cause losses to the state and society. This view of the broad negative impact can be seen in large corruption cases in Indonesia, such as the case of Bantuan Likuiditas Bank Indonesia (BLBI) in 1998 which contributed to the monetary crisis, or the Century Bank case in 2008 which caused the state to lose Rp. 6, 76 trillion as a result of setting the Bank Century as a failed bank with a systemic impact. ${ }^{31}$

Theoretically, there are at least three types of criminal purposes, namely absolute, relative and combined. ${ }^{32}$ The three goals of punishment reflect the will to be achieved from the existence of criminal law and punishment, where among the three have differences. The purpose of punishment is a

goal theory. This theory aims to prevent being divided into two forms of prevention specifically and in general. Prevention of the general public through the formulation of heavy crimes in articles of criminal offenses so that people are reluctant to commit crimes, special granting is shown to perpetrators where the criminal is used as a means of improving the perpetrators. Then the combined theory developed, Grotius and Hugo de Groot revealed criminality to criminals is fairness, but to what extent is the crime worthy of being charged? Vos as a follower of the combined theory expressed revenge and protection of the people. See : Eddy O.S Hiariej, above n 22, p. 31-43. 
manifestation of criminal sanctions as a reaction to a violation of the provisions of criminal law so that the placement of a corporation as the subject of criminal law must automatically also refer to the purpose of the sentence. The purpose of punishment according to the Draft National Criminal Code in Article 55 whose contents are as follows:

1. Punishment aims:

a. prevent criminal acts by enforcing legal norms for the protection and protection of society;

b. socializing convicts by holding coaching and mentoring so that they become good and useful people;

c. resolve conflicts caused by criminal acts, restore balance, and bring a sense of security and peace in society; and

d. Growing feelings of remorse and freeing guilt in the convicted person.

2. Criminalization is not intended to provide suffering and degrading human dignity.

Seeing the formulation above, the punishment in the paradigm of renewing national law, began to leave the retributive/absolute paradigm. Moreover, in the general explanation section of Law Number 12 Year 1995 concerning Corrections, it provides the basic reference that Indonesia as a country based on Pancasila has new thoughts on the function of punishment which is no longer merely

33 The involvement of corporations is one of the efforts to avoid criminal acts against corporate employees, because they can be weak parties. See: Sutan Remi Sjahdeini, Pertanggungjawaban Pidana Korporasi, (Jakarta: Grafiti Pers, 2007), p. 53 and 59.

34 As Mudzakkir argues, corporate punishment aims to provide legal protection to the community, prevent victimization due to corporate actions, and can increase state income due to a crime deterrence but also an attempt at social rehabilitation and reintegration criminals. Seeing the purpose of the sentence and correlating with the existence of the corporation as the subject of criminal law, the author has the following conclusions:

1) Making a corporation as the subject of criminal law is an alternative step of accountability for a criminal act (criminal responsibility not only for people but also for corporations), while at the same time reducing the reasoning of the legal subject of people. ${ }^{33}$

2) Giving criminal sanctions to corporations can provide the effect of prevention and protection of society at $\operatorname{large} \mathrm{e}^{34}$, as the purpose of punishment according to relative theory.

3) Giving criminal sanctions to corporations can also be intended as a means of resolving conflicts ${ }^{35}$ due to the existence of a crime.

Regarding the penalties or sanctions that can be imposed on corporations there are various forms, and for the Corruption Law itself, it recognizes several types of criminal sanctions for corporations, the first principal penalty which can only apply criminal penalties plus the maximum criminal provisions plus $1 / 3$ (one third) as contained in Article 20 paragraph (7). The two additional crimes contained in article 18 can be applied to all corporations.

The effort to include corporations as the subject of criminal law, which had

committed by the corporation. See: Putri Hikmawati, above n 27, 146.

35 Indonesian society with its Pancasila paradigm views crime as a disruption of evenwichtoring, harmony and harmony in people's lives which results in damage to individuals and society. So that punishment is a public reaction that aims to restore damage to balance, harmony, and harmony as a result of a criminal offense. See: Muladi, Lembaga Pidana Bersyarat (Bandung: Alumni, 1985), p. 56 and 60-61. 
implications for the opening of opportunities to convict corporations, is not smooth. There are contradictory opinions on the idea of including corporations as subjects of criminal law, which generally use the argument that corporations do not have "mens rea" (heart attitude) as an element of error according to the principle of "geen straf Zonder Schuld" (no criminal without error). "Mens rea" is only owned by the legal subjects of people, so everything he does is through the organs of his directors. ${ }^{36}$ In addition to being based on the principle of "geen strafZonder Schuld, contradictory opinions are also based on the principle of "societas delinquere non-potest" or "Universitas delinquere non-potest" (legal entities cannot commit criminal acts). ${ }^{37}$ Whereas for those who are pro against the placement of corporations as the subject of criminal law, they are based on several doctrines, including:

1) Principle of equality before the law, where treats corporations like humans (natuurlijk persoon) and burdens the responsibility for criminal acts made in line with the principle of law that anyone is equal before the law. ${ }^{38}$

2) Direct Corporate Criminal Liability Theory, which essentially states that the actions of certain agents of a corporation, as long as they are related to the corporation, are considered as actions of the corporation itself. ${ }^{39}$

3) Strict liability interpreted as a crime does not require the existence of "mens rea", but only requires the existence of an act. ${ }^{40}$ L.B. Curzon explained that the basis of this doctrine was one of the

36 Budi Suhariyanto, above n 11, 442.

37 Sutan Remy Sjahdeini, Pertanggungjawaban Pidana Korporasi (Jakarta: Grafiti Pers), p. 53.

38 Sutan Remy Sjahdeini, Ibid.

39 H.A. Palmer dan Henry Palmer as quoted Ali Mahrus, Asas-Asas Hukum Pidana Korporasi (Jakarta: PT RajaGrafindo Persada, 2013), p. 106. reasons for seeing the high level of social danger caused by the crimes committed. ${ }^{41}$

4) Vicarious liability is the concept of someone's responsibility for mistakes made by others, such as actions taken that are still within the scope of their work. 42 Because employers (corporations) have control and power over them (administrators and employees), and the profits that they get belong to the employer (corporation). ${ }^{43}$

For the author himself, the corporation is now right to be included as one of the subjects of criminal law, given that the type and modus operandi of crime are increasingly serious and it has a broad impact/victim, especially the community. Although the author agrees to place the corporation as the subject of criminal law, in terms of convicting corporations it must be wise to pay attention to the purpose of the punishment which is in line with the ideals of reforming Indonesian criminal law.

Criminalization against corporations who are perpetrators of corruption crimes had a purpose to be achieved, which the author based on the current enactment of the Corruption Law. The purpose of punishment for the corporation is: First, to restore losses to state finances, which are reflected in the form of sanctions "seizure of tangible or intangible movable or immovable property used for or obtained from criminal acts of corruption", and sanctions "as much as possible to pay substitute money. With assets obtained from corruption "as formulated in

40 Barda Nawawi Arief, Perbandingan Hukum Pidana (Jakarta: PT Rajawali Pers, 2002), p. 154.

41 Mahrus Ali, Asas-Asas Hukum Pidana Korporasi (Jakarta: Rajawali Pers, ), p. 114.

42 Barda Nawawi Arief, above n 40, p. 33.

43 C.M.V. Clarkson as quoted Mahrus Ali, above $n$ 41, p. 119. 
Article 18 paragraph (1) letter (a) and (b) of the Corruption Law, where the sanctions are included in the part of the types of additional sanctions. Secondly, to ensnare the corporation, which is reflected in the form of fines as a type of principal in the provisions of Article 20 paragraph (7) of the Corruption Law. The purpose of punishment in the form of trapping is rooted in the purpose of retaliation as in the doctrine of retributiveism in the Classical view. Johanes Andenaes said the main purpose of the crime is to satisfy the demands of justice that the imposition is solely to seek justice by taking revenge. ${ }^{44}$ Third, as a prevention measure, ${ }^{45}$ which is reflected in the form of sanctions "closure of all or part of the company for a maximum of 1 year" and sanctions "Revocation of all or part of certain rights or the elimination of all or part of certain profits" as stipulated in Article 18 paragraph (1) letters (c) and (d) Corruption Law

\section{b. Penalties Sanctions against Corporations as Criminal Sanctions in Corruption Crimes}

\section{1) Position of compensation for damages} in Indonesian positive criminal law

The form of criminal sanctions (criminal punishment) in Indonesian positive law consists of basic and additional criminal penalties and is regulated in Article 10 of the Criminal Code. This type of principal consists of capital punishment, imprisonment, confinement and fines, while additional types of criminal penalties include seizure of certain goods, criminal penalties for the revocation of certain rights, and the

44 Eddy O.S Hiariej, above n 22 , p.33.

45 Corporate punishment aimed at prevention is based on the results of studies conducted by the BPHN criminal law section in 1980/81. See: Muladi and Dwiwidja Priyatno, above n 4, p. 151.

46 The classic criminal aim is the purpose of imposition of criminal sanctions that focuses on criminal announcement of judges' decisions. In principle, this additional criminal is facultative, which means that in its decision, the panel of judges may or may not drop the additional type of criminal offence against someone who has been proven guilty. The imposition of this additional criminal type cannot stand alone as a basic crime, or in other words, this type of additional criminal must follow the existence of a basic crime.

In addition to recognizing the existence of the Criminal Code and Criminal Procedure Code, Indonesia's positive criminal law also recognizes the existence of various laws and regulations outside the Criminal Procedure Code as standing legal enforcement of criminal law in Indonesia. The position of various regulations outside the Criminal Procedure Code is "lex specialis", where if something to enforce criminal law is specifically regulated by the law, then it will override the provisions in the Criminal Code as "lex generalis". The enactment of a "lex specialis" provision also has implications for the regulation of criminal systems outside the Criminal Code which are specific and different from those stipulated in the Criminal Code. Criminal systems in principle are a way of realizing the purpose of punishment, so that in the dimension of reforming Indonesian criminal law regarding the purpose of punishment also experiences developments that cannot be separated from the objectives of modern criminal law. ${ }^{46}$ The development of the purpose of this punishment is the orientation of Indonesian criminal law to be in harmony with the sociocultural, socio-political, and socio-juridical

\footnotetext{
punished acts, different from the objectives of modern crimes, which are not only acts that are targeted by crimes, but also people who are known as dader-strafrecht. See:Eddy O.S Hiariej, above n 22, p. 25 .
} 
aspects reflected in the Pancasila. Also, criminals will need to pay attention to the position of parties outside the perpetrators, namely victims and the community.

The Corruption Law, as one of the laws that are "lex specialis", has a criminal structure that is different from that found in the Criminal Code. The difference lies in the rules regarding additional types of criminal acts in Article 18 paragraph (1) of the AntiCorruption Act, which recognizes four additional criminal forms, namely criminal: first, "seizure of tangible or intangible movable or immovable property used for or obtained from criminal acts of corruption, including convicted companies where criminal acts of corruption are committed, as well as goods that replace those items "; second, "payment of as much as possible substitute money with property obtained from corruption"; third, "closure of all or part of the company for a maximum of 1 year"; and fourth, "criminal Revocation of all or part of certain rights or the elimination of all or part of certain benefits, which have been or can be given by the Government to the convicted person". The existence of the provisions of Article 18 paragraph (1) does not necessarily negate the provisions of Article 10 of the Criminal Code, because in law enforcement corruption acts apply both articles.

Related to the subject of criminal law in the form of corporations, Muladi and Diah Sulistyani $^{47}$ said that there are around 62 laws in Indonesia that regulate that, which also illustrates various forms of criminal sanctions. Munir Fuady ${ }^{48}$ mentioning the existence of various forms of additional criminal sanctions, such as revocation of

47 Muladi and Diah Sulistyani, above n 28, p. 50-53.

48 Munir Fuady, above n 6, p.196.

49 M. Sholehudin, Sistem Sanksi Dalam Hukum Pidana (Ide Dasar Double Track System Dan permits, dissolution, compensation, the necessity to do something, a statement of apology to the people or to other parties who have been harmed, or revocation of certain other rights. Based on Munir Fuady's description, the compensation sanction (as the focus of this paper) has not been regulated as one of the types of sanctions in corruption in the Corruption Law. Indeed the Corruption Law recognizes additional sanctions in the form of payment of substitute money, the amount of which should not exceed the loss due to corruption committed by the perpetrator. But this is deemed by the author to be less relevant if it is dropped on the subject of corporate law, given the characteristics of the corporate crime that have been described previously, such as being organized and having serious and widespread impacts/victims. Also, sanctions for paying substitute money to the state are deemed to be less targeted, because the corporation has a function and social responsibility towards the surrounding community. Even though the consequences of corruption are not only detrimental to state finances but also harm the value of justice felt by the community. The value of community social justice in efforts to enforce the law of corruption is contained in the first paragraph of the general explanation section of Law 31 of 1999, which states: "To realize a just, prosperous, and prosperous Indonesian society, prevention efforts need to be continuously improved and eradication of criminal acts in general as well as criminal acts of corruption in particular".

Criminalization in the framework of reforming Indonesian criminal law must refer to the Pancasila philosophy ${ }^{49}$ as the soul of

Implementasinya), (Jakarta: PT Raja Grafindo Persada, 2003), p. 106-110. 
the Indonesian people, which demands a balance and harmony between the interests of individuals, communities, nations and countries. So that criminal law and punishment in Indonesia must be oriented to the balance of the interests of individuals (actors), and the interests of the community including victims of crime. Van Boyen defines victims as parties to crime schemes both individually and in groups that have suffered losses, including physical and mental injury, emotional suffering, economic loss or real deprivation of their basic rights, both because of action (by the act) and because of negligence ( by omission). ${ }^{50}$ According to Lilik Mulyadi, there are two types of rights that the victim has, namely procedural rights and service rights, where the right of service is carried out through compensation in the form of compensation, restitution, or an effort to return to the original condition. ${ }^{51}$ Arif Ghosita said that the victim has the right to be compensated for as a result of the occurrence of a criminal offence, ${ }^{52}$ especially about crimes committed by the corporation, so it is highly recommended that compensation be given due to the wide and serious impact.

The Criminal Procedure Code regulates the opportunity to be able to award compensation through means of combining criminal cases with civil law, namely in Article 98 up to Article 101 of Law Number 8 Year 1981 concerning Criminal Procedure Law. But the combination of compensation claims is limited to material losses, not including immaterial losses. Another disadvantage is that if a criminal case is not carried out a legal remedy, the legal claim filed by the victim cannot be requested for

50 Rena Yulia, Viktimologi: Perlindungan Hukum Terhadap Korban Kejahatan, (Yogyakarta: Graha Ilmu, 2013), p. 50. legal action. Then related to victims' restitution rights, which are regulated in Law Number 13 Year 2006 concerning the Protection of Witnesses and Victims in conjunction with Law Number 31 Year 2014 concerning the Regulation of the Act on Law Number 13 Year 2006 concerning Protection of Witnesses and Victims. However, the law does not explain the perpetrator as a corporation, as well as the limitation of compensation rights only for gross violations of human rights violations.

Other weaknesses in compensation (restitution and compensation) are not integrated into the criminal justice system, so there is no binding force. It is different if it is integrated into the criminal justice system with a judge's decision that has binding legal force and the power of execution that has legal certainty. Actually, at this time there has been a known settlement of corruption cases outside the criminal justice line or commonly referred to as the non-criminal approach (in addition to the approach through criminal or criminal justice). The non-penal approach is the use of a civil law mechanism, with the terms/conditions of the case not having enough evidence to be prosecuted criminally and in the case of the death of the defendant, as stipulated in Article 31 up to Article 34 of Law 31 of 1999. This nonreasoning is very possible to apply to the subject of criminal law in the form of a person, and it is not possible for a corporation because of the condition that the "defendant dies".

Sanctions for compensation as a form of criminal sanctions are regulated in a number of regulations outside the Criminal Code, one of which is Law No. 8 Year 1999

51 Lilik Mulyadi, Bunga Rampai Hukum Pidana Perspektif Teoritik Dan Praktik, (Jakarta: Alumni, 2008), p. 408.

52 Rena Yulia, above n 50, p. 43. 
concerning Consumer Protection Article 63, which reads: "Against criminal sanctions as referred to in Article 62, additional penalties may be imposed, in the form of: a. seizure of certain goods; $b$. announcement of the judge's decision; c. compensation payment; $d$. order to terminate certain activities that cause consumer losses; e. obligation to withdraw goods from circulation; or $f$. revocation of business license ". There is no phrase which states that all of them are "additional crimes" in the formulation, but looking at the forms of sanctions and seeing their relevance to Article 62 which regulates criminal sanctions, the author can interpret that this is a type of additional criminal sanction. Taking into account the recognition of compensation sanctions for corporations as perpetrators of crimes in the consumer field, there is no harm if these compensation sanctions are also possible to apply to corporate actors in criminal acts of corruption.

Sanctions for compensation for corporations who commit corruption have a fundamental difference with the types of sanctions for payment of substitute money as stipulated in the current Anti-Corruption Law. The most principal difference is regarding its purpose, where sanctions for payment of substitute money are aimed at returning state losses as a result of criminal acts of corruption, while these compensation sanctions are intended as a means of resolving conflicts due to the occurrence of criminal acts of corruption between corporate actors and the public. This compensation penalty also differs from the issue of the

53 Budi Suhariyanto, 'Restoratif Justice Dalam Pemidanaan Korporasi Pelaku Korupsi Demi Optimalisasi Pengembalian Kerugian Negara' (2016), 5.3 (December) Rechsvinding 421, 422. According to Budi Suhariyanto, through restorative justice, it is expected that the corporation will become cooperative in returning the financial losses of the country being corrupted rights of restitution of perpetrators to victims which are currently regulated in the Witness and Victim Protection Act, where the right of refusal is submitted/petitioned by the victim to the court, while for compensation later through the prosecutor's demands. Even the regulation regarding compensation sanctions can open the opportunity for settlement through a restorative justice approach. ${ }^{53}$ In addition, ideally the right to restitution is possible for victims who are of a noncommunity nature who are broad and communal, and ideally those who are "prosecuted" to pay for the right to restitution are perpetrators who are individuals and not corporations.

Provision of sanctions for corporations who commit corruption should be taken wisely. Although there are other sanctions such as sanctions "closure of all or part of the company for a maximum of 1 year" and "Revocation of all or part of certain rights or the elimination of all or part of certain profits" as stipulated in Article 18 paragraph (1) letter $\mathrm{c}$ and $\mathrm{d}$ the Corruption Law, this must be considered about the side effects if the sanctions are imposed. It is undeniable that corporations have a very important role in the development process in the economic field, where the role of corporations in the development of their activities can increase economic growth through the inclusion of the state in the form of taxes and even foreign exchange, and the provision of extensive employment for the community. In view of this, Yoshio Suzuki's opinion in his book "The Role of Criminal Law in the Control of

without having to face prosecution before the trial. His opinion is seen by the author as quite relevant if it is associated with the idea of compensation sanctions by corporations who are corruptors, because it is possible to reach an agreement between the corporation and the community in an effort to resolve conflicts due to corruption. 
Social and Economic Offenses" seems to be quoted by Muladi, where caution must be exercised in corporate convictions, especially regarding the two sanctions in Article 18 paragraph (1) letters $\mathrm{c}$ and $\mathrm{d}$, because it will have a very broad impact. The imposition of the two types of sanctions opens up the possibility of suffering that is not only accepted by the corporation, but also for workers who will be threatened with termination of employment. So that compensation sanctions for corporate perpetrators of corruption are expected to be a middle way of achieving the goal of conviction that sets the values of social justice for the people of Indonesia, as well as a means of law enforcement.

\section{2) The Idea of Corporate Penalty Sanctions in Corruption in Indonesia}

Moving on from what was stated by Herbert L. Packer on the existence of criminal sanctions in people's lives that are very necessary for dealing with crimes but also as a real threat to the community, the use of criminal sanctions for legislation needs to be done properly and correctly. ${ }^{54}$ Moreover, it was associated with the opinion of Yoshio Suzuki above, as well as the opinion of Budi Suhariyanto regarding the idea of corporate depenalization of corruption perpetrators based on rational reasons related to national economic stability (including the fate of employees / corporate workers) that could trigger the emergence of crises in various fields, the imposition of sanctions on the corporation must be carried out wisely and carefully. Paying attention to these considerations, the issue of law enforcement on corporations who commit corruption must be based on reasoning policies that are in line

54 Dey Ravena and Kristian, Kebijakan Kriminal (Jakarta: Kencana, 2017), p. 114. with the ideals of reforming Indonesian criminal law.

First and second paragraphs General explanation of Law 31 of 1999 concerning Eradication of Corruption Crime mandates the following:

"National development aims to realize Indonesian people as a whole and Indonesian society as a whole that is fair, prosperous, prosperous, and orderly based on Pancasila and the Indonesian Constitution. To realize this just, prosperous, and prosperous Indonesian society, efforts need to be continually improved prevention and eradication of criminal acts in general and criminal acts of corruption in particular.

During national development efforts in various fields, the aspirations of the community to eradicate corruption and other forms of irregularities have increased, because in reality corruption has caused enormous losses to the state which in turn can have an impact on the emergence of crises in various fields. For this reason, efforts to prevent and eradicate corruption need to be intensified and intensified by upholding human rights and the interests of society."

This general explanation illustrates the existence of integration between criminal law policies (reason policy), and social policies and criminal policies. Crime prevention efforts are essentially an integral part of social protection efforts and efforts to achieve social welfare, so the main purpose of criminal politics is to provide protection for the community and to achieve public welfare. ${ }^{55}$ Efforts to improve public welfare

${ }^{55}$ Criminal politics is part of social policy, which is interpreted by Sudarto as a rational effort by the community in tackling crime. While Marc Ancel 
(as one of the directions of social policy) are through a criminal policy approach (as a crime prevention effort), namely by increasing efforts to prevent and eradicate corruption, because these crimes can have an impact on state losses which have implications for the ideals of national development. The crime prevention efforts can be implemented through reasoning facilities, namely through the enforcement of criminal law as a form of a means of reasoning policy that upholds human rights and the interests of society.

It is not wrong if Law Number 31 Year 1999 in the explanation section mentions "public interest" as something that should not be forgotten in terms of law enforcement of corruption so that in terms of law enforcement, corruption should be neglected regarding the position of the community as victims. As Mardjono Reksodiputro's opinion $^{56}$, that the loss of the community due to corruption should not only be seen from economic losses (material, pen), but also that are not less important and greater are those which are immaterial losses in the form of public trust in the government and the private sector (corporations, pensioners). Specifically regarding the perpetrators of corporate crime which is quite relevant about corruption, is the opinion of Kristian ${ }^{57}$ regarding social and moral losses in the form of damage to public trust in business people, because such crimes are integrated into a legitimate business structure. It is the social interest of the community that is not currently

formulated criminal policy as a rational control of crime by society. G. Peter Hoefnagels is clearer in interpreting criminal policies, namely the science of reactions in dealing with crime, tackling crime, designing behavior for crime prevention. See: Yaris Adhial Fajrin and Ach Faisol Triwijaya, 'Pencegahan Korupsi Pasca Putusan MK Nomor ... Op.cit.', 46.

56 As quoted: M. Arief Amrullah, Perkembangan Kejahatan Korporasi, Dampak Dan reached by law in the context of law enforcement against corporations who are corruptors. The sanctions against corporations who are currently corruptors are only intended as a means of prevention, moreover as a means of deterrence, and sanctions that have not been seen as a means of resolving conflicts are felt by the community. Or in other words, the sanctions that exist today do not reflect efforts to restore the public's sense of trust towards corporations in particular corruption, and it can have an impact on eroding public trust in business people (corporations) in general. Sanctions for substitute money payments that are currently available the only function to restore state losses due to corruption, but have not touched reconciliation values between corporations as actors with the community.

Attention to "the interests of the community" is also part of the rule of reform of Indonesian criminal law as stated by Barda Nawawi Arief. According to him the rule of renewal of national criminal law includes the monodualistic balance between society and individuals. ${ }^{58}$ These balance values will lead to the ideals of social justice for all the people of Indonesia as mandated by the fifth principle of Pancasila and also as a basis for the social policies contained in the general explanation section of Law Number 31 the Year 1999 concerning Eradication of Action Corruption Crime. Corporate relations with the issue of the social interests of the community are also reflected in the existence

Permasalahan Hukum (Jakarta: Kencana, 2018), p. 65.

57 Kristian, above n 29, 586.

58 Monodualistic ideas are values derived from Pancasila. Monodualistic values refer to the nature of Indonesian human beings as personal beings as well as social beings. See: Muladi, Beberapa Catatan Berkaiatan Dengan RUU KUHP Baru, (Batam, 2004). 
of corporate social responsibility (CSR) as a corporate responsibility to the community. CSR aims as a corporate social investment to get a positive image or view, as part of the company's business strategy, to obtain community support for the company, and part of the company's risk management to reduce and avoid social conflicts caused by the existence of the company. ${ }^{59}$ Regulatory CSR is regulated in Law Number 40 Year 2007 concerning Limited Liability Companies, where it is an obligation of the Company whose implementation is carried out by observing propriety and fairness. A brief description of the CSR illustrates that the existence of a corporation cannot be separated from its social and moral obligations and responsibilities towards the environment and its community so that all the consequences of corporate activities (both positive and negative) must be accountable to one of them.

The return of the results of corruption is not an excuse to erase the error, so in other words, it illustrates the law enforcement of criminal acts of corruption leads to the principle of "primum remidium". Paying attention to this direction, a sanction is needed that can accommodate the interests of all parties, whether corporate, community and state actors and not merely to provide deterrence or retaliation. Munir Fuady revealed that currently there are models of non-conventional criminal penalties that are deemed suitable for a corporation that has committed a crime, one of which is: Community Service Punishment for corporate crime that has a negative impact on the community, so that the community it received a kind of compensation from the

59 Meilanny Budiarti and Santoso Tri Raharjo, 'Corporate Social Responsibility (CSR) Dari Sudut Pandang Perusahaan' (2014), 4.1 (June) Jurnal SHARE Social Work Journal 13, 15. results of the execution of the sentence. ${ }^{60}$ The absence of criminal sanctions aimed at resolving conflicts due to corruption carried out by corporations has provided room for new ideas regarding the regulation of compensation sanctions for the corporation. Efforts to incorporate current cases as stipulated in the Criminal Procedure Code also have weaknesses, so that by including compensation sanctions as a type of additional sanctions in criminal law regarding eradicating corruption is a middle way to achieve law enforcement goals as well as efforts to prioritize the interests of society. The positive impact of the imposition of compensation sanctions is:

1) As a means of resolving conflicts as the purpose of punishment in the dimensions of national criminal law reform;

2) Returning public/community trust to corporations who are corruptors in particular, and other (corporate) business actors in general;

3) Returning losses due to corruption, both materially and immaterial;

4) Reducing reasoning to corporate managers;

5) Avoiding types of sanctions that can harm employees/employees of the corporation; and

6) Open opportunities for using the restorative justice approach in efforts to resolve corruption cases committed by corporations.

Giving sanctions for compensation to the corporation for the perpetrators of corruption is actually to give the burden of responsibility due to the occurrence of these crimes to the corporation and the compensation is intended for the benefit of

60 Munir Fuady, Doktrin-Doktrin Modern Dalam Corporate Law Dan Eksistensinya Dalam Hukum Indonesia, (Bandung: Citra Aditya Bakti, 2002), p. 29. 
the community. That responsibility is part of the correctional process and helps harmonize the company and society. ${ }^{61}$

The idea of compensation penalties for corporations who commit corruption does not collide with the provisions of existing sanctions, such as fines and sanctions for payment of substitute money. Penal sanctions as a type of principal can be imposed simultaneously with the compensation sanction as an additional sanction, in which penalty penalties have a limit of the amount that is limitations. Limitation of fines sanctions is possible not to achieve the number of losses caused by criminal acts of corruption so that the sanctions are intended as means of deterrence.

Material state losses can be returned through sanctions for payment of substitute money by corporate actors so that the purpose of "redemption" can be achieved through these sanctions. Whereas sanctions for compensation to corporations as perpetrators of corruption are a means of reconciliation, guidance, reintegration, resocialization, or as a means of conflict resolution, so that compensation sanctions, in this case, are not always in the form of nominal money (material) because these sanctions are more immaterial and immediately felt/accepted by the community. Sanctions for compensation need to be based on the judge's decision as a way to have the power to press on the corporation of the perpetrators of corruption to account for their actions to the community.

Regarding the extent and locus of the people who receive compensation, it can be seen from the magnitude of the loss or impact of the crimes committed by the corporation,

61 Yusrizal, 'Tanggung Jawab Korporasi Terhadap Korban Kejahatan Tindak Pidana Lingkungan and by paying attention to the place of residence as the scene of the crime. The idea of the author regarding the application of compensation sanctions to corporations that commit criminal acts as a renewal step for National criminal law which is oriented towards resolving conflicts between perpetrators and victims while at the same time presenting a balance between individuals and society.

\section{CONCLUSION AND SUGGESTION}

Corporations can be categorized as one of the legal subjects in criminal acts of corruption because corporations to achieve the objectives of obtaining profit are made illegally. The current purpose of pipetting begins to be directed toward the urgency of renewal of criminal law which begins to abandon the paradigm of retaliation. Current criminalization should be based on Pancasila as a basic idea that is not oriented to the punishment but as rehabilitation and social reintegration to criminals.

Positioning corporations as the subject of criminal law in corruption crimes should be directed to three main objectives; Restore the country's financial losses, ensnare corporations and preventive efforts. However, criminal rationing for corporations raises the issue of national economic stability. The author considers the selection of criminal types that impact the deterrent effect but still positioning the social interests of society as well as the values of balance can be realized with criminal damages. Criminal damages against corporations who commit future corruption crimes are expected to be a solution to provide a pattern of balance between crime prevention and a very 
important corporate existence. This balance pattern is a national criminal law reform direction as a form of compromise of some interests.

\section{Book}

\section{REFERENCES}

Amrullah, M. Arief, Perkembangan Kejahatan Korporasi, Dampak Dan Permasalahan Hukum (Jakarta: Kencana, 2018).

Mahrus, Ali, Asas-Asas Hukum Pidana

Korporasi (Jakarta: PT RajaGrafindo Persada, 2013).

Arief, Barda Nawawi, Perbandingan Hukum

Pidana (Jakarta: PT Rajawali Pers, 2002).

Fuady, Munir, Doktrin-Doktrin Modern Dalam Corporate Law Dan Eksistensinya Dalam Hukum Indonesia, (Bandung: Citra Aditya Bakti, 2002).

, Munir, Teori-Teori Besar (Grand

Theory) Dalam Hukum, (Jakarta:

Kencana, 2013).

Hiariej, Eddy O.S., Prinsip-Prinsip Hukum

Pidana, (Yogyakarta: Cahaya Atma

Pustaka, 2014),

Kristian, Hukum Pidana Korporasi:

Kebijakan Integral (Integral Policy)

Formulasi Pertanggungjawaban

Pidana Korporasi Di Indonesia,

(Bandung: Nuansa Aulia, 2014).

Sholehudin, M., Sistem Sanksi Dalam

Hukum Pidana (Ide Dasar Double

Track System Dan Implementasinya),

(Jakarta: PT Raja Grafindo Persada, 2003).

Muladi, Lembaga Pidana Bersyarat

(Bandung: Alumni, 1985).

$\begin{array}{rr}\text { and Diah } & \text { Sulistyani, } \\ \text { Pertanggungjawaban } & \text { Pidana }\end{array}$

Korporasi (Bandung: Alumni, 2013). and Dwiwidja Priyatno,
Pertanggungjawaban

Pidana

Korporasi (Jakarta: Kencana, 2015).

Mulyadi, Lilik, Bunga Rampai Hukum

Pidana Perspektif Teoritik Dan

Praktik, (Jakarta: Alumni, 2008).

Ravena, Dey and Kristian, Kebijakan Kriminal (Jakarta: Kencana, 2017).

Sjahdeini, Sutan Remi, Pertanggungjawaban

Pidana Korporasi, (Jakarta: Grafiti Pers, 2007).

Subekti, Pokok-Pokok Hukum Perdata, (Jakarta: Intermasa, 1984).

Susanto, I.S., Kejahatan Korporasi (Semarang: Badan Penerbit Universitas Diponegoro, 1995).

Yulia, Rena, Viktimologi: Perlindungan Hukum Terhadap Korban Kejahatan, (Yogyakarta: Graha Ilmu, 2013).

\section{Journal}

Bressler, Martin S., 'The Impact of Crime on Business: A Model for Prevention, Detection \& Remedy' (2009), 7.5 (May) Journal of Management and Marketing Research 1.

Budiarti S, Meilanny and Santoso Tri Raharjo, 'Corporate Social Responsibility (CSR) Dari Sudut Pandang Perusahaan' (2014), 4.1 (June) Jurnal SHARE Social Work Journal 13.

Fajrin, Yaris Adhial and Ach Faisol Triwijaya, 'Pencegahan Korupsi Pasca Putusan MK Nomor 71 / PUU / XIV / 2016 Melalui Pendekatan Kebijakan' (2019), 9.1 (May) HUMANI (Hukum Dan Masyarakat Madani) 30.

Hikmawati, Puteri, 'Kendala Penerapan Pertanggungjawaban Pidana Korporasi Sebagai Pelaku Tindak Pidana Korupsi' (2017), 8.1 (June) Jurnal Negara Hukum 131.

van Erp, Judith, 'The Organization of Corporate Crime: Introduction to 
Special Issue of Administrative Sciences' (2018), $8.3 \quad$ (July)

Administrative Sciences 36.

Kristian, 'Urgensi Pertanggungjawaban Pidana Korporasi' (2014), 44.4 (October-December) Jurnal Hukum dan Pembangunan 575.

Shanty, Lilik, 'Aspek Teori Hukum Dalam Kejahatan Korporasi' (2017), 3.1 (January-June) Pakuan Law Review 56.

Suhariyanto, Budi, 'Pertanggungjawaban Pidana Korporasi Berdasarkan Corporate Culture Model Dan Implikasinya Bagi Kesejahteraan' (2017), 6.3 (December) Rechsvinding 441.

Budi, 'Progresivitas Putusan Pemidanaan Terhadap Korporasi Pelaku Tindak Pidana Korupsi' (2016), 16.2 (Juni) De Jure 201. , Budi, 'Restoratif Justice Dalam Pemidanaan Korporasi Pelaku Korupsi Demi Optimalisasi Pengembalian Kerugian Negara' (2016), 5.3 (Desember) Rechsvinding 421.

Vanderstraeten, Raf, 'Systems Everywhere?' (2019), 36.3 (April) Systems Research and Behavioral Science 1-8.

Yusrizal, 'Tanggung Jawab Korporasi Terhadap Korban Kejahatan Tindak Pidana Lingkungan Hidup' (2012), 14.2 (August) Kanun Jurnal Ilmu Hukum 217.

\section{News}

Rachman, Dylan Aprialdo, "Perjalanan Kasus PT NKE, Korporasi Pertama yang Divonis Korupsi", https://nasional.kompas.com /read/2019/01/04/06115311/perjalanan -kasus-pt-nke-korporasi-pertamayang-divonis-korupsi?page=all.Akses tanggal 1 Juli 2019.
Ramadhan, Bilal. Ini Kronologis Kasus Bank Century. https://www.republika.co.id/berita/nas ional/hukum/14/03/06/n20q0m-inikronologis-kasus-bank-century. Akses tanggal 21 Juli 2019.

\section{Others}

Agatha Olivia Victoria, "Penerimaan Pajak Hingga Juli 2019 Hanya Tumbuh $2,68 \% "$

https://katadata.co.id/berita/2019/08/2

6/penerimaan-pajak-hingga-juli-2019hanya-tumbuh-268

Muladi, Beberapa Catatan Berkaiatan Dengan RUU KUHP Baru, (Batam, 2004)

Syarifah, Nur, Mengupas Permasalahan Pidana Tambahan Pembayaran Uang Pengganti dalam Perkara Korupsi, Lembaga Kajian \& Advokasi Independensi Peradilan, 8 Desember 2015, http://leip.or.id/mengupaspermasalahan-pidana-tambahanpembayaran-uang-pengganti-dalamperkara-korupsi/\#_ftn1, diakses: 21 Juli 2019. 